\title{
Stereotype Development in Andalusian Children
}

\author{
Almudena Giménez de la Peña ${ }^{1}$, Jesús M. Canto Ortiz ${ }^{1}$, Pablo Fernández Berrocal ${ }^{1}$, \\ and Martyn Barrett ${ }^{2}$ \\ ${ }^{1}$ University of Malaga \\ ${ }^{2}$ University of Surrey
}

Social psychologists have shown a profound interest in intergroup relationships, but there are very few papers focusing on the developmental aspects that explain the psychological mechanisms involved in the construction of group and cultural identity. Our research aims to explore how the self-categorization of Andalusian children evolves. We tried to assess the degree to which they self-identify as Andalusian, Spanish, and European, and how this identification changes with age. We were also interested in the affective evaluation of different groups (French, Italian, English, German, Spanish, Catalonian, and Andalusian) made by Andalusian children. Furthermore, we analyzed the relationship between selfcategorization and the evaluation of these groups. Results show that the development of national (autonomous community) identity in these children is influenced by their cognitive development, as well as by the relationships among the regional communities of Spain and the relationships between Spain and other countries. The peculiarity of Andalusians as a group is that they assume both identities: Spanish and Andalusian, from a very early age. In-group favoritism is an extended phenomenon at all ages, and Andalusian children have a negative stereotype of the other Spanish groups and other European communities. Keywords: stereotypes, social identity, intergroup relations

Los psicólogos sociales manifiestan un profundo interés por las relaciones intergrupales. Sin embargo, hay pocas publicaciones relacionadas con los aspectos evolutivos que explican los mecanismos psicológicos implicados en la construcción de la identidad grupal y cultural. Nuestra investigación ha pretendido estudiar cómo evoluciona la autocategorización de los niños andaluces. También hemos evaluado el grado en que la identificación de los niños como andaluces, españoles y europeos cambia con la edad. Al mismo tiempo, nos interesaba conocer cómo los niños andaluces evalúan a diferentes grupos (franceses, italianos, ingleses, alemanes, españoles, catalanes y andaluces). Igualmente, hemos analizado la relación entre la autocategorización y la evaluación de esos grupos. Los resultados muestran que el desarrollo y adquisición de la identidad nacional está influida tanto por los aspectos cognoscitivos (indicados por la edad) como por las relaciones entre las comunidades de España y las relaciones entre España y otros países. La peculiaridad de los andaluces como grupo es que asumen la identidad como español y como andaluz desde una edad muy temprana. El favoritismo endogrupal es un fenómeno extendido a todas las edades, de ahí que los niños andaluces tengan un estereotipo más negativo de los exogrupos.

Palabras clave: estereotipos, identidad social, relaciones intergrupales

The preparation of this paper was funded by a grant from INTAS (International Association for the Promotion of Cooperation with Scientists from New Independent States of the former Soviet Union), The development of national ethnolinguistic and religious identity in children and adolescents living in the NIS. ref. 97-1363.

Correspondence concerning this article should be addressed to: Almudena Giménez de la Peña, Facultad de Psicología, Universidad de Málaga, 29071 Málaga, Spain. E-mail: almudena@uma.es 
Research on the psychological processes by which children construct their social and cultural identity is an area of increasing interest (Barrett \& Short, 1992). At present, the internal structure of nations is being affected by important events, such as constant migration from poor to rich countries or claims by nationalist parties for acknowledgement of their rights from their state's central power. In this context, it is of great interest to know how children acquire the concepts of nation and their national identity, and how they begin to manifest their first prejudices towards other groups (Breakwell $\&$ Lyons, 1996). During the 1950s and 60s, a number of studies were carried out on children's construction of social and cultural identity (Middleton, Tajfel, \& Johnson, 1970; Piaget \& Weil, 1951; Tajfel \& Jahoda, 1966; Tajfel, Jahoda, Nemeth, Rim, \& Johnson, 1972). After some years during which work in this area almost ceased, research in children's social cognition (Shantz, 1983) and their cognitive representations (Mandler, 1983), and the consolidation of the psychology of intergroup relationships (Brewer \& Miller, 1996; Sedikides, Schopler, \& Insko, 1998) renewed researchers' interest, which was also boosted by an increase in national movements, changes to national frontiers, and the emergence of new countries in Europe.

Piaget and Weil (1951) carried out one of the first studies in this area. They assumed that the concept of nation should develop parallel to cognitive abilities. Consequently, children would not have a complete concept of their own country until the age of 10 , because only after achieving a certain level of cognitive maturity would they be able to comprehend the concepts of country and nation. However, these authors' assumption of 5- and 6-year-old children's inability to elaborate well-structured points of view about their own and other countries is not supported by the results obtained in other studies (Lambert \& Klineberg, 1967).

Tajfel, Jahoda, Nemeth, Rim, and Johnson (1972), working with 6- and 11-year-old participants from Scotland, England, and Israel, found that even the youngest children showed a clear preference for their own country. In fact, a number of studies have found that children in general show marked identification with their in-group, whereas children from minority groups manifest more ambivalent attitudes (Asher \& Allen, 1969; Brand, Ruiz, \& Padilla, 1974; Morland, 1969). Nevertheless, social changes may modify this tendency. Children from minority groups show a clear preference for their own group when these minority groups claim more social acceptance and strive to reduce discriminatory treatment (Aboud, 1980).

Young children also express prejudiced attitudes and discriminatory behavior towards out-groups (Brown, 1995). Three-year-olds have been found to be aware of social categories such as ethnic group and sex. The review by Williams and Morland (1976) confirmed the presence of strong ethnic awareness in 4-year-olds. In addition, Thompson (1975) found that $90 \%$ of 3 -year-old children could correctly classify pictures of people as men or women (see Slaby \& Frey, 1975; Yee \& Brown, 1994). Hence, there is evidence that children are aware, from an early age, of the categorical divisions of sex and ethnic group in their social environment. They also express negative stereotypes toward out-groups, and positive bias toward their own ethnic group (Van Avermaet \& McClintock, 1988) and their own sex (Zalk \& Katz, 1978). In relation to sex bias, Zalk and Katz (1978) found that children showed positive bias toward their own sex, and that this was stronger in girls than in boys, and more pronounced in younger children (aged between 7 and 10 years) than in children over 10 .

Thus, children express prejudices about relevant social categories, such as ethnic group and sex, and these prejudices fluctuate with age. Some models (Aboud, 1988; Maccoby, 1988) associate the development of prejudices with the general affective and socio-cognitive changes that take place during the first 10 years of life. Such models confer a relevant role on the categorization process. From this perspective, children are considered active agents in the construction of categories, rather than passive receptors of the prejudices prevalent in their social environment. In sum, children's cognitive development is affected and modulated by the specific socio-cultural contexts in which they live (Barrett, 2000). The peculiarities of the social context in which children are brought up influence their cognitive development, and subsequently, the content and structure of their social categories.

With regard to the acquisition of the concept of nation, relevant studies (e.g., Barrett \& Short, 1992; Jahoda, 1962; Lambert \& Klineberg, 1967; Tajfel \& Jahoda, 1966) have revealed a lack of concordance between the development of the concepts country, nation, or ethnic group, on the one hand, and evaluation of the social groups that comprise them, on the other. Tajfel pointed out that children very often acquire value judgments about foreigners at the age of six or seven, although they have barely any factual knowledge about these people (Johnson, Middleton, \& Tajfel, 1970; Tajfel \& Jahoda, 1966). Lambert and Klineberg (1967) found that children might have information about the national group that they like, whereas they know very little about the groups that they dislike. These results suggest that, from a developmental perspective, the evaluation of out-groups precedes knowledge and comprehension of them.

More recently, Barrett and Short (1992) carried out a study that supports the same idea. They asked a sample of 216 English children (aged between 5 and 10 years) to express their knowledge about four European countries: France, Germany, Spain, and Italy. Their results confirmed that children develop national stereotypes made up of sets of features assigned to different foreign countries. In addition, the children provided affective responses before having developed clear knowledge about the countries. Even more interesting is the fact that, once acquired, these affective responses were stable over time. These results show children's high level of preference for their own group even 
before constructing, comprehending, and adequately using the concept of country or nation. This is more pronounced in children from majority or higher-status groups.

For many people, regional and national identity constitute an important part of their social identity (Barrett, Wilson, \& Lyons, 1999). As Barrett (2000) pointed out, national identity involves cognitive, affective, and behavioral aspects. People who identify themselves with a nation are aware of the existence of their national group, they categorize themselves as members of this group, and they know their national emblems and the geographical characteristics of the national territory. At the same time, these people know the stereotypes associated with their nation and they share the stereotypes attributed to other nations. From an affective point of view, people may vary in the degree of attachment to their country and in their involvement as members of a nation. There are also differences in the impact that the national feeling has on a person's self-esteem. The theory of social identity (Hogg \& Abrams, 1988; Tajfel \& Turner, 1979) assumes that the achievement of a high level of selfesteem is a strong motivational factor that affects the way people construct their social identity. People emphasize those characteristics that reflect a positive image of their national group, while ignoring or neglecting negative features. Thus, identifying oneself as a member of a nation contributes to reinforcing one's self-esteem.

The theory of self-categorization (Turner, 1987) defines self-concept as a set of cognitive representations of the self. It proposes that self-categorization is represented at different levels of abstraction. At the supraordinate or most abstract level, people identify themselves as human beings. The basic level corresponds to belonging to a social group, that is, social identity. Personal identity refers to the subordinate or most concrete level of categorization. Although Turner proposed these three levels of self-categorization, he admitted that finer levels of categorization could be established. For example, at the social identity level, regional, national, and other superior categories may be distinguished.

A number of investigations have been carried out to study the stereotypes that Spanish people have with regard to the inhabitants of different regions of Spain (Javaloy, Cornejo, \& Bechini, 1990; Rodríguez \& Moya, 1998; Sangrador, 1996). In a recent paper, Giménez, Canto, Fernández, and Barrett (1999) reported that Andalusian children and adults show very similar stereotypes, and that there was high consistency between the Andalusian selfstereotype and the stereotype that people from other Spanish communities have with regard to Andalusian people. At the same time, there was a tendency to have a more positive stereotype of the in-group than of different out-groups.

The purpose of our research is to analyze the acquisition and development of stereotypes (Giménez et al., 1999) that Andalusian children construct of five European nationalities (France, Italy, England, Germany, and Spain) and two Spanish communities (Andalusia and Catalonia). We examined the evolution of self-categorization and its relation to the affective evaluation of one's own nationality and of out-groups (other nationalities). We also explored participants' degree of selfidentification as Andalusian, Spanish, and European, and its evolution with age (6 to 15 years). Compared to regions such as Catalonia or the Basque Country, in Andalusia there is no independent nationalist (autonomous community) sentiment. On the contrary, most Andalusians feel very Spanish (Huici, Ros, Cano, Hopkins, Emler, \& Carmona, 1997). For this reason, we expected to find that Andalusian children develop positive stereotypes towards their ingroups (Andalusian and Spanish), but negative stereotypes towards their outgroups (Catalonian and other nationalities).

\section{Method}

\section{Participants}

Two hundred and forty-six children participated in this study. The main group was divided into four age groups, as follows: 60 six-year-olds (29 boys, 31 girls), $M=6.74, S D$ $=0.31 ; 60$ nine-year-olds ( 25 boys, 35 girls), $M=9.42 ; S D$ $=0.42 ; 66$ twelve-year-olds ( 32 boys, 34 girls), $M=12.26$; $S D=0.62$; and 60 fifteen-year-olds ( 39 boys, 21 girls), $M$ $=15.63 ; S D=0.42$. They were all from two public schools in the city of Málaga (Andalusia, Spain).

\section{Procedure}

Children were tested individually in a quiet room at their school. They responded to an interview schedule (see Appendix I) from which we selected two items to meet the aims of this study.

In order to measure the importance for the participants of their self-categorization, they were shown a set of 11 cards. Each card bore the name of a category: Spanish, Andalusian, Malaganian (malagueño, from Málaga or its province), Catalonian, and European (regional identities); girl and boy (to allow the assessment of gender identification); and 6 years, 9 years, 12 years, and 15 years (age). The experimenter spread the cards over the table and asked the children to read each label. The children were then told that all these words could be used to describe them. Once the experimenter was sure the children had understood the labels (categories), they were asked, "If you had to choose just one of these cards because it was the most important for you, which one would you choose?" This procedure was repeated until 6 of the cards had been removed, one at a time, (only one of the gender cards was left). As the child had to choose six cards, each card was scored 1-6, corresponding to the order in which it was selected $(1=$ first selection, the most important for the child. $6=$ final selection, the least important for the child). Although the maximum score for each Andalusian participant in the selected cards was 6 , higher 
scores could be found. This is because the Andalusian sample forms part of a wider study in which one Catalonian group, two British, and two Italian groups were included. The cards Catalonian, French, British, German, and Italian formed part of the general study. To guarantee uniformity of scoring and to facilitate subsequent data analysis of the whole group we considered all the possible selections. The non-selected cards received a mean score resulting from the sum of the possible scores: $(8+9+10+11+12) / 5=10$. Due to this correction, mean scores could exceed 7 points.

The second question included in this study evaluated the children's representation of their own group and of other national/regional groups. Children aged 6 to 12 years were given a set of cards with an adjective written on each one. There were positive and negative adjectives with opposite meanings: clean-dirty, happy-sad, peaceful-aggressive, cleverstupid, hardworking-lazy, friendly-unfriendly, and nice-not nice. Participants were then given a box labeled Spanish. They were asked to look at the adjectives and put into the box those that describe Spanish people. Fifteen-year-olds were shown the list of adjectives and requested to assign the adjectives to Spanish people. The same procedure was repeated with the remaining nationalities (British, French, Italian, German, Catalonian, and Malaganian). The order of presentation was randomized for each child. Positive adjectives were scored as 1 , negative adjectives as -1 , and don't know responses as 0 .

\section{Results}

Results are organized following the three goals mentioned at the beginning of the study.

\section{The Development of Self-Categorization}

In order to examine the development of self-categorization, data from the first question were subjected to a one-way ANOVA by age group. Being Spanish was very important for the children at any age (see Table 1), and this value did not change in the different age groups, $F(3,242)=1.36, p$ $=.25$. They also felt very Andalusian, and the feeling of being Andalusian persisted as they grew older, $F(3,242)=25.93$, $p<.0001$. Tukey HSD post-hoc analysis showed significant differences $(p<.01)$ between the group of 6-year-olds and the 9- and 12-year-olds, respectively.

At the age of 6 , the children did not categorize themselves as Malaganian. Between ages 9 and 12, selfcategorization as Malaganian increased, and then decreased in adolescence, $F(3,242)=5.63, p<.001$.

Being European was not important for 6-year-old children. This category is a late acquisition, becoming progressively more important with age, until the age of 15 , when participants used the European category more frequently to self-categorize, $F(3,242)=20.082, p<.001$. The post-hoc Tukey test showed significant differences $(p$ $<.01$ ) between the 6- and 9-year-olds, on the one hand, and the 12- and 15-year-olds, on the other. Adolescents selfcategorized as very Spanish, very Andalusian, quite Malaganian, and $a$ bit European.

\section{The Development of Stereotypes}

We also conducted ANOVAs on the positive indexes to establish the way children evaluate different groups and whether they have a more positive attitude toward their own group. Positive indexes resulted from the sum of the section of positive adjectives (clean, happy, peaceful, clever, hardworking, friendly, and nice). The results showed how the positive evaluation of different nationalities changes with age (all $p s<.001)$. Six-year-old children made a positive evaluation of Spanish people, $F(3,242)=23.71, p$ $<.001$, and Andalusian people, $F(3,242)=22.58, p<.001$ (see Table 2). The post-hoc Tukey test showed significant differences $(p<.01)$ between the 6-year-olds and the other age groups, and between the 9- and 12-year-olds and the 15-year-old group in the evaluation of both Spanish and Andalusian people. We did not find intra-subject differences between the positive evaluation of Spanish and Andalusian

Table 1

Mean Level of Self-Categorization Scales as a Function of Age

Self-Categorization Scales

\begin{tabular}{|c|c|c|c|c|c|c|c|c|}
\hline \multirow[t]{2}{*}{ Age Groups } & \multicolumn{2}{|c|}{ European } & \multicolumn{2}{|c|}{ Spanish } & \multicolumn{2}{|c|}{ Andalusian } & \multicolumn{2}{|c|}{ Malaganian } \\
\hline & $M$ & $S D$ & $M$ & $S D$ & $M$ & $S D$ & $M$ & $S D$ \\
\hline 6 years $(n=60)$ & 7.92 & 2.69 & 3.68 & 2.96 & 6.38 & 3.54 & 4.58 & 3.39 \\
\hline 9 years $(n=60)$ & 6.55 & 2.92 & 3.09 & 2.08 & 3.58 & 2.78 & 2.98 & 2.49 \\
\hline 12 years $(n=66)$ & 4.78 & 2.93 & 3.03 & 1.18 & 2.94 & 1.14 & 2.89 & 1.51 \\
\hline 15 years $(n=60)$ & 4.72 & 2.10 & 3.08 & 1.57 & 3.16 & 1.73 & 3.99 & 3.06 \\
\hline$F(3,242)$ & \multicolumn{2}{|c|}{$14.11 * * *$} & \multicolumn{2}{|c|}{1.36} & \multicolumn{2}{|c|}{$25.93 * * *$} & \multicolumn{2}{|c|}{$5.63^{* * *}$} \\
\hline
\end{tabular}

$* * * p<.001$ 
Table 2

Mean Level of Self-Categorization Scales as a Function of Age

\begin{tabular}{|c|c|c|c|c|c|c|c|c|c|c|c|c|c|c|}
\hline \multirow{3}{*}{ Age Groups } & \multicolumn{14}{|c|}{ Index of positive categorization } \\
\hline & \multicolumn{2}{|c|}{ Andalusian } & \multicolumn{2}{|c|}{ Catalonian } & \multicolumn{2}{|c|}{ Spanish } & \multicolumn{2}{|c|}{ Italian } & \multicolumn{2}{|c|}{ French } & \multicolumn{2}{|c|}{ British } & \multicolumn{2}{|c|}{ German } \\
\hline & $M$ & $S D$ & $M$ & $S D$ & $M$ & $S D$ & $M$ & $S D$ & $M$ & $S D$ & $M$ & $S D$ & $M$ & $S D$ \\
\hline 6 years & 4.46 & 1.79 & 2.50 & 2.28 & 4.55 & 1.73 & 2.10 & 1.9 & 2.68 & 2.25 & 2.48 & 2.06 & 1.68 & 1.5 \\
\hline 9 years & 5.43 & .92 & 3.41 & 2.14 & 5.53 & .87 & 3.85 & 1.84 & 4.10 & 1.50 & 3.86 & 1.74 & 3.68 & 2.03 \\
\hline 12 years & 5.18 & 1.12 & 2.54 & 1.95 & 5.36 & 1.13 & 3.46 & 1.98 & 3.93 & 1.82 & 3.77 & 1.89 & 3.19 & 1.63 \\
\hline 15 years & 3.51 & 1.63 & 1.60 & 1.61 & 3.53 & 1.90 & 1.80 & 1.54 & 1.83 & 1.52 & 2.55 & 1.63 & 1.96 & 1.48 \\
\hline$F(3,242)$ & \multicolumn{2}{|c|}{$22.58 * * *$} & \multicolumn{2}{|c|}{$8.12 * * *$} & \multicolumn{2}{|c|}{$23.71 * * *$} & \multicolumn{2}{|c|}{$17.33 * * *$} & \multicolumn{2}{|c|}{$21.83 * * *$} & \multicolumn{2}{|c|}{$10.26 * * *$} & \multicolumn{2}{|c|}{$17.40 * * *$} \\
\hline
\end{tabular}

$* * * p<.001$

people, $t(60)=-.31, p=.10$. Differences were found between Spanish and Catalonian, $t(60)=6.68, p<.001$, Spanish and Italian, $\mathrm{t}(60)=7.99, p<.001$, Spanish and French, $t(60)=$ 5.96, $p<.001$, Spanish and British, $\mathrm{t}(60)=7.15, p<.001$, and Spanish and German, $\mathrm{t}(60)=9.19, p<.001$.

At 9 and 12 years, similar results were obtained. Not only did the positive evaluation of the Spanish stereotype improve, but so did that of the out-groups.

The positive scores of all (in- or out-groups) stereotypes showed a decrement at the age of 15, although the order of preference remained the same: Spanish and Andalusian, followed by British, French, Italian, German, and Catalonian.

When the representation of different national stereotypes and the way they are grouped were analyzed, two clearly differentiated categories appeared: Spanish and Andalusian were grouped together, whereas the remaining nationalities were included in the other group.

A factor analysis with varimax rotation was applied to determine whether the data fit a two-factor model (see Table 3 ). Two factors accounted for $68.1 \%$ of the total variance and were labeled: "Spain" and "Europe." Spanish and Andalusian formed two overlapping categories with very similar factor loadings. The Catalonian category was grouped together with the European factor, and its values were the same as the French category.

Table 3

Factor Loadings (Varimax) of Rotated Factors from the Positive Indexes

\begin{tabular}{lcc}
\hline Positive index & $\begin{array}{c}\text { Factor 1 } \\
\text { Spanish }\end{array}$ & $\begin{array}{c}\text { Factor 2 } \\
\text { European }\end{array}$ \\
\hline Andalusian & .873 & \\
Spanish & .894 & \\
Catalonian & & .766 \\
Italian & & .731 \\
French & .766 \\
British & .777 \\
German & .765 \\
\hline
\end{tabular}

\section{Discussion}

The development and acquisition of Andalusian children's national identity is influenced by their cognitive development as well as by the relationships between the regional communities of Spain, and the relations established between Spain and other countries. In addition to being familiar with some aspects of their national identity, and identifying themselves as members of their nation, children evaluate and develop feelings about their own group and other national groups (Barrett \& Short, 1992).

Similarly to the way Andalusian adults feel both Andalusian and Spanish (Giménez et al., 1999; Huici et al., 1997), Malaganian children of all ages consider being Spanish very important. Being Andalusian is not as important as being Spanish, although the importance of the former increases with age. Therefore, it could be concluded that national and regional identities are important during childhood, and that this may persist with age (Barrett, Wilson, \& Lyons, 1999).

The peculiarity of Andalusian people as a group, in contrast to other communities of Spain (e.g., Catalonia), is that they assume both the Spanish and the Andalusian identities at the same level. Six-year-old children already show this tendency. Surprisingly, being Malaganian is not a salient feature for the youngest children, but gains relevance with age. It is important for 9- and 12-year-old children, although the strength of the identification declines at 15. Identity as European citizens is an adolescent achievement, but it does not mean becoming less attached to the Spanish and Andalusian identification. Fifteen-yearolds feel very Spanish and Andalusian, very Malaganian, and a bit European.

In-group favoritism is an extended phenomenon at all ages (Barrett, 2000). In our study, children perceived their nation and region more positively than the rest of the nations. At the age of 6, Andalusian children evaluate Andalusian and Spanish people very positively. However, they assign a more negative evaluation to Catalonian, British, French, Italian, and German people. Between 9 and 12 there is a general positive increase in the evaluation of all groups, 
with Spanish and Andalusian being the most positively evaluated. A change in the responses of 15-year-olds is observed in the increase of variability attributed to the ingroup. Despite the strengthening of national and regional identification, all groups are perceived as being less compact and more variable than they were at early ages (Barrett, Wilson, \& Lyons, 1999), while all groups also receive lower evaluations (Barrett \& Short, 1992).

Andalusian children, as was found in adult populations (Rodríguez \& Moya, 1998), have a negative stereotype of the other Spanish group (Catalonians) under study. Their stereotype of Catalonian people is more negative than those of British, French, Italian, and German people. Children share adults' stereotype (Giménez et al., 1999), and assume the same prejudices as those associated with national or foreigner out-groups. The content of the stereotype of Catalonian people is quite similar to that of the most rejected European stereotype (Giménez et al., 1999). Catalonian people are perceived as a very different group, with an image more similar to that of foreigners than to that of Spanish people. Given that Andalusian children perceive their selfdescription of being both Spanish and Andalusian as perfectly compatible, the more Andalusian they feel, the more they like Spanish people and the more they reject the Catalonians. These findings support the assumptions of the social identity theory (Tajfel \& Turner, 1979). In-group identification induces in-group favoritism, which is reflected in the children's prejudiced image of Catalonian and other social out-groups, and in a positive image of the in-groups (Andalusian and Spanish).

Self-categorization at a medium level (that is, at an intergroup level) may be multiple (Turner, 1987). A person may perceive himself as a man, young, student, Andalusian, Spanish, liberal, and so on. Some of these categories are exclusive (e.g., man and young), whereas others are inclusive, as their relationship is hierarchical (e.g., Spanish and Andalusian). Our results support this hypothesis of multiple self-categorization. The Andalusian population identifies closely with the regional and national categories. An Andalusian citizen does not perceive any contradiction in self-categorizing as Andalusian and, at the same time, Spanish. Thus, in our research, in-group favoritism extends to the Spanish and Andalusian categories. In fact, Andalusian and Spanish stereotypes are very similar (Giménez et al., 1999).

Malaganian children's feeling "as much Andalusian as Spanish" causes them to develop very positive selfstereotypes of both nationalities, clearly distinguished from the stereotypes of other nationalities. Hence, they build a positive self-image, because, on the one hand, it includes the positive elements of the social identity with which they feel identified, and, on the other, they perceive themselves as very different from the out-groups with which they do not feel identified, and which they evaluate negatively (Tajfel \& Turner, 1979). As obtaining a high level of self-esteem is an important factor that influences the way people construct their social identity, emphasizing the positive features of one's national and regional groups while ignoring their negative aspects contributes to strengthening selfesteem.

Thus, in our research, the development of national identity has once more been found to be determined not only by children's cognitive development (Aboud, 1988), but also by social influence and the relationships established among different regions and nations. Therefore, at the same age, children brought up in different social and cultural contexts may display differences not only in the content of their national/regional identity, but also in the way in which it is constructed (Barrett, 2000).

\section{References}

Aboud, F.E. (1980). A test of ethnocentrism with young children. Canadian Journal of Behavioral Science, 12, 195-209.

Aboud, F.E. (1988). Children and prejudice. Oxford, UK: Blackwell.

Asher, S.R., \& Allen, V.L. (1969). Racial preference and social comparison processes. Journal of Social Issues, 25, 157-166.

Barrett, M. (2000, March). The development of nation identity in childhood and adolescence. Inaugural lecture presented at the University of Surrey, UK.

Barrett, M., \& Short, J. (1992). Images of European people in a group of 5-10 year old schoolchildren. British Journal of Developmental Psychology, 10, 339-369.

Barrett, M., Wilson, H., \& Lyons, E. (1999, April). Selfcategorization theory and the development of national identity in English children. Paper presented at the Biennial Meeting of the Society for Research in Child Development, Albuquerque, NM.

Brand, E.S., Ruiz, R.A., \& Padilla, A.M. (1974). Ethnic identification and preference: A review. Psychological Bulletin, $81,860-890$

Breakwell, G.M., \& Lyons, E. (1996). Changing European identities. Social psychological analyses of social change. London: Surrey University Press.

Brewer, M.M., \& Miller, N. (1996). Intergroup relations. Pacific Grove, CA: Brooks-Cole.

Brown, R. (1995). Prejudice. Its social psychology. London: Blackwell.

Giménez, A., Canto, J.M., Fernández, P., \& Barrett, M. (1999). La identificación social como regulador del estereotipo: lo que piensan los niños andaluces. Boletín de Psicología, 64, 81-99.

Hogg, M.A., \& Abrams, D. (1988). Social identifications: A social psychology of intergroup relations and group processes. London: Routledge.

Huici, C., Ros, M., Cano, I., Hopkins, N., Emler N., \& Carmona, M. (1997). Comparative identity and evaluation of sociopolitical change: Perceptions of the European Community as a function of the salience of regional identities. European Journal of Social Psychology, 27, 97-113. 
Jahoda, G. (1962). Development of Scottish children's ideas and attitudes about other countries. Journal of Social Psychology, 58, 91-108.

Javaloy, F., Cornejo, J.M., \& Bechini, A. (1990). España vista desde Cataluña: estereotipos étnicos en una comunidad plural. Barcelona, Spain: PPU.

Johnson, N. (1966). What do children learn from war comics? New Society, 8, 7-12.

Lambert, W.E., \& Klineberg, O. (1967). Children's view of foreign: A cross-national study. New York: Appleton Century Crofts.

Maccoby, E.E. (1988). Gender as social category. Developmental Psychology, 24, 755-765.

Mandler, J. (1983). Representation. In P. H. Mussen (Ed.), Handbook of child psychology (pp. 123-155). New York: Wiley,

Middleton, M., Tajfel, H., \& Johnson, N. (1970). Cognitive and affective aspects of children's national attitudes. British Journal of Social and Clinical Psychology, 9, 122-134.

Morland, J.K. (1969). Race awareness among American and Hong Kong Chinese children. American Journal of Sociology, 75, 360-374.

Piaget, J., \& Weil, A. (1951). The development in children of the idea of the homeland and of relations with other countries. International Social Science Bulletin, 3, 561-578.

Rodríguez, R., \& Moya, M.C. (1998). España vista desde Andalucía. Estereotipos e identidad. Psicología Política, 16, 27-48.

Sangrador, J.L. (1996). Identidades, actitudes y estereotipos en la España de las autonomías. Madrid: CIS.

Sedikides, C., Shopler, J., \& Insko, C. (1998). Intergroup cognition and intergroup behavior. Hillsdale, NJ: Erlbaum.

Shantz, C.U. (1983). Social cognition. In P. H. Mussen (Ed.). Handbook of child psychology. Vol. III: Cognitive Development. New York: Wiley.
Slaby, R.G., \& Frey, K.S. (1975). Development of gender constancy and selective attention to same-sex models. Child Development, 46, 849-856.

Tajfel, H., \& Jahoda, G. (1966). Development in children of concepts and attitudes about their own and other nations: A cross-national study. Proceedings of the 18th International Congress in Psychology, Moscow, Symposium, 36, 17-33.

Tajfel, H., Jahoda, G., Nemeth, C., Rim, C.Y., \&. Johnson, N. (1972). The devaluation by children of their own national and ethnic group: Two case studies. British Journal of Social and Clinical Psychology, 11, 235-243.

Tajfel H., \& Turner, J.C. (1979). The social identity theory of intergroup behavior. In S. Worchel \& W. G. Austin (Eds.), Psychology of intergroup relations (pp. 232-261). Chicago, IL: Nelson-Hall.

Thompson, S.K. (1975). Gender labels and early sex-role development. Child Development, 46, 339-347.

Turner, J.C. (1987). Rediscovering the social group: A selfcategorization behavior. Oxford, UK: Blackwell.

Van Avermaet, E., \& McClintock, L.G. (1988). Intergroup fairness and bias in children. European Journal of Social Psychology, 18, 407-427.

Williams, J.E., \& Morland, J.K. (1976). Race, color, and the young child. Chapel Hill, NC: University of North Carolina Press.

Yee, M.D., \& Brown, R.J. (1994). The development of gender differentiation in young children. British Journal of Social Psychology, 33, 133-196.

Zalk, S.R., \& Katz, P.A. (1978). Gender attitudes in children. Sex Roles, 4, 349-357.

Received 27 June 2002 Revision received 25 March 2003 Accepted 31 March 2003 